\title{
Nurses empowerment at primary health care centers and its relation with quality of work life
}

\author{
Fatma Rushdy Mohamed ${ }^{* 1}$, Safaa Rashad Mahmoud ${ }^{2}$, Karima Hosny Abdel Hafez ${ }^{1}$, Thorea Mohamed Mahmoud ${ }^{3}$ \\ ${ }^{1}$ Nursing Administration Department, Faculty of Nursing, Assiut University, Egypt \\ ${ }^{2}$ Community Nursing Department, Faculty of Nursing, Assiut University, Egypt \\ ${ }^{3}$ Community Nursing Department, Faculty of Nursing, Sohag University, Egypt
}

Received: June 3, 2019

Accepted: June 24, 2019

Online Published: July 25, 2019

DOI: $10.5430 /$ jnep.v9n10p79

URL: https://doi.org/10.5430/jnep.v9n10p79

\begin{abstract}
Background and objective: Nurses in primary health care are a considerable group of professionals working in the health sector and an adequate quality of working life will empower them to provide favorable quality care to their clients. Further, a better quality of working life can keep the employees focused and support them to strive effectively towards the organization's vision. The aim of the study was to explore the relationship between nurses' empowerment and quality of work life at primary health care centers in Assiut City.

Methods: This study was conducted in a descriptive correlated manner; the population consisted of the Assiut city primary health care centers nursing staff $(n=85)$. Self-administered questionnaire consisted of three parts: 1 st part-Personal characteristics data questionnaire, 2nd part-Work Empowerment Promoting Factors Scale, and 3rd part: Quality of Nurses' Work Life questionnaire.

Results: There were significant negative correlations between quality of work life and empowerment factors among studied nurses.

Conclusions and recommendations: Workshops on the quality of work life skills for nurses and nurse managers should be done periodically, nurse managers in $\mathrm{MCH}$ centers should provide nurses by sufficient information, guide and resources, Nurses in primary health centers have to remain allowed to participate in decision making process to empower them, as like properly as growing theirs effect on autonomy, and First line nurse managers should periodically have nursing group meeting to verbalized, vitalize and support peer and social interaction.
\end{abstract}

Key Words: Empowerment, Quality of work life, Nurses, Primary health care centers

\section{INTRODUCTION}

Empowerment builds and strengthens the confidence of people about themselves which results in increasing effort in the direction of the effectiveness of the organization's activities. Empowerment is considered from two perspectives. First view empowerment is seen as the organization's activities due to sharing staffs of power and decisions. In this view creating the conditions is necessary for staff to getting stronger.
The second view is according to conformity with a psychological empowerment perspective, that is, a gut feeling in persons who can make independent decisions in their work process. In this view, it considers the attitude of people towards action and theirs function into the corporation in the organization. ${ }^{[1,2]}$

The quality of working Life (QWL) is critical for healthcare

\footnotetext{
*Correspondence: Fatma Rushdy Mohamed; Email: drfatmarushdy@ yahoo.com; Address: Nursing Administration, Faculty of Nursing, Assiut University, Egypt.
} 
organizations to attract and retain qualified, committed and motivated employees. The quality over cause lifestyles refers after an employee's satisfaction including work life. It shows the alliance among employees or their physical, communal or pecuniary job environment. It is a multi-dimensional idea and covers an employee's emotions about various quantities on work. These encompass the assignment content, pursuit conditions, integrity and enough compensation, profession improvement opportunities, assignment discretion, participation of decision-making, occupational health and safety, work stress, action security, organizational yet interpersonal relations or work-life balance. ${ }^{[3-5]}$ Quality of work life is meant to realize judgment fulfillment, assisting them in accordance with take care change then preservation on staff. ${ }^{[6]}$

Quality regarding work existence is the response of representatives as regards work, specifically. It is important to make the expert wants then impassioned wellbeing results. Utilizing that definition, multiplication regarding labor life focuses round property or how according to decorate the feature perception in conformity with addresses individual issues. As a way so attribute elements regarding assignment life, that incorporates business enterprise stability, compensation, phrase associated pride, needs and thought at work, consultant relations, yet contract on staff, expert success, yet activity regarding workers. The relationship concerning quality of job lifestyles and employee empowerment is a two-way connection and each one contributes to make profitability for the organization. So the quality about deed life is a fundamental factor into the enabling staff. ${ }^{\text {[7] }}$

The personnel may ascribe wish from theirs work lives solely now the critical expectation in regard to their place of work is suitably fulfilled. Therefore, companies necessity in imitation of focus regarding the work thing of the employees in conformity with excite advantageous attitude then conduct via self-worth, self-esteem then tremendous identification at the workplace. Further, theirs job function need to encompass the concepts on empowerment, participative management, yet self-leadership. The empowered labor environment do facilitate the employees in accordance with workout their complete potent because reaching the organizational consequences. ${ }^{[8]}$

Quality of work life refers to overall satisfaction with work life along with a accretive sense over belonging in imitation of a deed group, becoming oneself, then existence necessary or respectable. QWL contains over favorableness about the total work environment, sense over servant good then innovations that targets person satisfaction, enhances organizational effectiveness and productivity. ${ }^{[9]}$

Primary care has come to be a priority of chief fitness health structures development. Health care personnel have a key role in this work. ${ }^{[10]}$ Since nursing rank is the biggest team so many factories among populace health institutions, he increasingly more grow to be necessary in major care, neighborhood health or ignoble non-hospital roles. ${ }^{[11]}$

Public health nurses are the primary players into the community. Health promotion, prevention, institutional care, or rehabilitation functions are the quintessential performance about nurses in accordance with the fitness seriousness system. Despite theirs integral function within the health seriousness system, nurses stay as much the invisible team of workers of fitness outweigh shipping rule. ${ }^{[12]}$

Professional nurses reported that nurse retention in public healthcare facilities is negatively affected by poor working conditions consisting of workload, inadequate payment system, and absence about expert autonomy, limited career improvement possibilities or the respective absence regarding administration then leadership styles. Quality of work life is being accepted as the foremost criterion for attracting and retaining the human resources required for quality and sustainability of the healthcare system. ${ }^{[13]}$

\subsection{The significance of the study}

There is no doubt that the quality of work life is a good sign and indicator for organizational empowerment because empowerment creates and sustains a work environment that speaks to values that facilitate the employee's choice to invest in and own personal action and behaviors resulting in positive contributions to the organization's mission. In spite of the important role of primary health care nurses in providing preventive and curative health care, an exploration of previous literature on the few studies has discussed this topic. Also, Organizational efforts towards better QWL are less prevalent in the healthcare sector of developing countries. Evidence shows that nursing shortage, poor attribute on nurse's action life, work dissatisfaction yet terrible patient consequences are immediately linked after absence over healthful job environment. ${ }^{[14,15]}$ So, the researchers need to explore Nurses' Empowerment at Primary Health care Centers and its' relation with Quality of work Life in Assiut city.

\subsection{Aim of the study}

The aim of the study is to explore Nurses' Empowerment at Primary Health care Centers and its' relation with Quality of work Life in Assiut city.

\subsection{Research questions}

- Do the empowerment factors have the ability to predict the work-life quality?

ISSN 1925-4040 E-ISSN 1925-4059 
- What are the relationships among nurses' personal characteristics, empowerment and quality of work life?

\section{Subject And Method}

\subsection{Design}

A descriptive correlational design was utilized for the current study.

\subsection{Setting}

This study was conducted in all Maternal and Child Health Centers (MCH) in Assuit City (Kulta, Kedwany, El-Walidia, El-Arbaen and El-Hamara, and Gharb elbalad). The work system in $\mathrm{MCH}$ centers is divided into two shifts; morning and afternoon except for El-walidia center which provides services for 24 hours a day. Functions of MCH centers included premarital care including premarital examination, counseling, and health education. Maternity care including antenatal care, natal, and postnatal care (through home visits). Infant and preschool child care (such as immunization and follow-up). Family planning services (through appropriate counseling). Dental clinic services. Health education (through mother's class).

\subsection{Sample}

The total number of the study sample in all $\mathrm{MCH}$ centers was 85 nurses. All nurses included in the study without exclusion criteria. -Kulta: 10 nurses, Kedwany: 10 nurses, El-Walidia: 18 nurses, El-Arbeen: 19 nurses, El-Hamara: 14 nurses, Gharb elballad 14 nurses, with the total number of 85 nurses.

\subsection{Data collection}

The self-administered questionnaire consisted of three parts:

Part I-Personal characteristics data questionnaire: It involved data as a place of work, age, qualification, marital status, and years of experience.

Part II-Work Empowerment Promoting Factors Scale (WEPS): It consists of twenty seven items structured in six empowerment categories: (empowerment meaning (EM) includes (3 items), empowerment competence (EC) includes ( 3 items), self determination (ES) includes ( 3 items), empowerment impact (EI) includes (3 items), procedural justice (P) includes (6 items), interactional justice (I) includes ( 9 items). A questionnaire sheet was developed by Shelton. ${ }^{[16]}$ The scoring system of this questionnaire is a five-point Likert scale ranging from strongly agree (5) to strongly disagree (1).

Part III-Quality of nurses' work life (QNWL) questionnaire that constructed by Brook ${ }^{[17]}$ to determine nurses' work life

Published by Sciedu Press quality. The questionnaire consists of 35 items and it has five factors (Work Environment, Relations with managers, Work Conditions, Job perception, and Support Services). Each statement was scored in a 6-point scale ranging from "strongly disagree (1 point)" and "strongly agree (6 points)".

\subsection{Pilot study}

It fulfilled to test questionnaire reliability, feasibility, applicability, and served in estimating the time needed for filling the questionnaire. It was carried out on ten nurses that included in the total sample of the primary health care centers in Assiut city because there were no necessary modifications done for the study tool. Data collected from the pilot study were analyzed. The questionnaire would take about 15-20 minutes for filling. The reliability of the two previous tools was assessed in a pilot study by measuring their internal consistency using Cronbach's alpha coefficient method. This turned to be $\alpha=0.80$ for the quality of nurses' work life, $\alpha$ $=0.92$ for work empowerment promoting factors scale. The validity of the study tools were assessed by 5 experts in the Nursing Administration specialty.

\subsection{Fieldwork}

Official permission was obtained from the primary health care centers directors, before the beginning of data collection. The actual data collection started in October 2018 and ended in November 2018. The researchers met the targeted nurses, explained to them the purpose of the study, and obtained form them their oral consent to participate. Those who agreed to participate were given the tool and asked to fill them out and return them anonymously in the same setting or at most the next day.

\subsection{Ethical considerations}

The participants' oral consent was obtained after informing them about their rights to participate, refuse, or withdraw at any time. Total confidentiality of any obtained information was ensured. The study maneuver could not entail any harmful effects on participants.

\subsection{Statistical analysis}

Statistical analysis was done using SPSS 19.0 Statistical Software Package after data entry. Data were analyzed by using descriptive statistics in the form of frequencies, mean, standard deviation and range. ANOVA and $t$-test were used for evaluation of the inter-relationships among quantitative variables. Statistical magnitude was considered at $p$-value $\leq$ .05 . 


\section{RESUlts}

Table 1 revealed personal characteristics of studied nurses All the nurses were females, $35.3 \%$ of them were aged less than 30 yrs. $82.4 \%$ had Secondary School of Nursing Diploma, $87.1 \%$ were married, and $90.6 \%$ had 10 and more years of experiences. As illustrated in Table 2, the highest mean scores were interactional justice \& procedural justice of empowerment factors among the studied nurses (26.43 \pm $12.10 \& 16.82 \pm 7.62)$ respectively, these indicated that both factors are found and applied in $\mathrm{MCH}$ centers.

Table 1. Distribution of personal characteristics of nurses at primary health centers in Assiut city $(n=85)$

\begin{tabular}{lll}
\hline Personal characteristics & $\begin{array}{l}\text { Nurses } \\
(\mathbf{n}=\mathbf{8 5})\end{array}$ \\
\hline Age (years) & No. & $\%$ \\
22- less 30 yrs. & 14 & 16.5 \\
30- less 35 yrs. & 30 & 35.2 \\
35- less 40 yrs. & 22 & 25.9 \\
40 yrs and More. & 19 & 22.4 \\
Mean \pm SD & $3.42 \pm 1.22$ \\
Educational Qualification & \multicolumn{2}{|c}{} \\
Secondary school of the Nursing Diploma. & 70 & 82.4 \\
Technical Institute of Nursing. & 3 & 3.5 \\
Bachelor Degree in Nursing. & 12 & 14.1 \\
Marital status & \multicolumn{2}{|}{} \\
Single & 5 & 5.9 \\
Married & 74 & 87.1 \\
Divorced & 4 & 4.7 \\
Widow & 2 & 2.3 \\
Years of Experience in Primary Health care Setting & \\
1- less 5 yrs. & 3 & 3.5 \\
5- less 10 yrs. & 5 & 5.9 \\
10 yrs and More. & 77 & 90.6 \\
Mean \pm SD & $3.87 \pm 0.43$ \\
\hline
\end{tabular}

According to Table 3, the highest mean scores were work conditions \& work environment of work life quality factors between studied nurses $(40.64 \pm 7.71 \& 33.97 \pm 9.57)$ respectively, these indicated that both factors are efficient in $\mathrm{MCH}$ centers.

Table 2. Nurses' empowerment factors mean scores at primary health centers in Assiut city $(n=85)$

\begin{tabular}{ll}
\hline \multirow{2}{*}{ Empowerment factors } & Nurses \\
\cline { 2 - 2 } & Mean \pm SD \\
\hline -Empowerment Meaning & $5.70 \pm 3.37$ \\
-Empowerment Competence & $6.02 \pm 3.00$ \\
-Empowerment Self-Determination & $6.98 \pm 3.04$ \\
-Empowerment Impact & $7.20 \pm 3.16$ \\
-Procedural Justice & $16.82 \pm 7.62$ \\
-Interactional Justice & $26.43 \pm 12.10$ \\
\hline
\end{tabular}

Table 3. Nurses' work life quality factors mean and standard deviation at Primary Health Centers in Assiut city $(n=85)$

\begin{tabular}{ll}
\hline Quality of work life factors & Nurses \\
\cline { 2 - 2 } & Mean \pm SD \\
\hline -Work environment. & $33.97 \pm 9.57$ \\
-Relations with a manager. & $20.68 \pm 4.63$ \\
-Work conditions. & $40.64 \pm 7.71$ \\
-Job perception. & $30.52 \pm 7.55$ \\
-Supportive services. & $15.51 \pm 5.49$ \\
\hline
\end{tabular}

Table 4 presented significant negative correlations between work life quality and empowerment factors among studied nurses.

Table 5 demonstrated that there were significant positive correlations between Empowerment Self-Determination, Empowerment Impact, Procedural Justice, Interactional Justice factors with age among nurses $(6.242 * * \& 4.659 * * \&$ $7.018 * * \& 7.182 * *)$ respectively. In addition, there were significant positive correlations between Empowerment Impact \& Procedural Justice factors with marital status among nurses $(3.724 * * \& 3.401 * *)$ respectively.

Table 4. Relation between the empowerment factors and quality of work life scores at primary health centers in Assiut city $(\mathrm{n}=85)$

\begin{tabular}{|c|c|c|c|c|c|c|}
\hline \multirow{2}{*}{$\begin{array}{l}\text { Quality of work life } \\
\text { factors }\end{array}$} & \multicolumn{6}{|c|}{ Empowerment Factors } \\
\hline & $\begin{array}{l}\text { Empowerment } \\
\text { Meaning }\end{array}$ & $\begin{array}{l}\text { Empowerment } \\
\text { Competence }\end{array}$ & $\begin{array}{l}\text { Empowerment } \\
\text { Self-Determination }\end{array}$ & $\begin{array}{l}\text { Empowerment } \\
\text { Impact }\end{array}$ & $\begin{array}{l}\text { Procedural } \\
\text { Justice }\end{array}$ & $\begin{array}{l}\text { Interactional } \\
\text { Justice }\end{array}$ \\
\hline Work environment & -0.089 & $-0.299 * *$ & $-0.286^{* *}$ & $-0.318 * *$ & $-0.418^{* *}$ & $-0.449 * *$ \\
\hline Relations with a manager & -0.306 & $-0.309 * *$ & $-0.448 * *$ & $-0.441 * *$ & $-0.431 * *$ & $-0.496^{* *}$ \\
\hline Work conditions & $-0.370 * *$ & $-0.332 * *$ & $-0.434 * *$ & $-0.471 * *$ & $-0.263^{*}$ & $-0.303^{* *}$ \\
\hline Job perception & $-0.407 * *$ & $-0.279 * *$ & $-0.491 * *$ & $-0.542 * *$ & $-0.343^{* *}$ & $-0.402 * *$ \\
\hline Supportive services & -0.159 & -0.065 & $-0.449 * *$ & $-0.454 * *$ & $-0.736^{* *}$ & $-0.708 * *$ \\
\hline
\end{tabular}

${ }^{*} p$-value $\leq .05 ; *{ }^{*} p$-value $\leq .001$. 
Table 5. Correlation between empowerment factors scores and nurses' personal characteristics at primary health centers in Assiut city $(\mathrm{n}=85)$

\begin{tabular}{|c|c|c|c|c|c|c|}
\hline \multirow{2}{*}{$\begin{array}{l}\text { Personal } \\
\text { Characteristics }\end{array}$} & \multicolumn{6}{|c|}{ Empowerment Factors } \\
\hline & $\begin{array}{l}\text { Empowerment } \\
\text { Meaning }\end{array}$ & $\begin{array}{l}\text { Empowerment } \\
\text { Competence }\end{array}$ & $\begin{array}{l}\text { Empowerment } \\
\text { Self-Determination }\end{array}$ & $\begin{array}{l}\text { Empowerment } \\
\text { Impact }\end{array}$ & $\begin{array}{l}\text { Procedural } \\
\text { Justice }\end{array}$ & $\begin{array}{l}\text { Interactional } \\
\text { Justice }\end{array}$ \\
\hline $\operatorname{Age}^{\#}$ & 0.372 & 0.374 & $6.242 * *$ & $4.659 * *$ & $7.018^{* *}$ & $7.182 * *$ \\
\hline Qualification & 0.178 & 2.307 & 1.765 & 0.017 & $3.804 *$ & 1.790 \\
\hline Marital status & 2.335 & 1.098 & 1.040 & $3.724 * *$ & $3.401 * *$ & 2.285 \\
\hline Years of experience & 0.022 & 0.728 & 0.416 & 0.388 & 0.324 & 0.559 \\
\hline
\end{tabular}

${ }^{\#}$ Pearson correlation coefficient; ${ }^{*} p$-value $\leq .05 ;{ }^{* *} p$-value $\leq .001$.

Table 6 illustrated significant positive correlations between the studied nurses $\left(6.614^{* *}, 11.318^{* *}, 8.540^{* *}, 6.893^{* *}\right.$ age and work environment, relations with a manager, work $\left.\& 8.419^{* *}, p<.001\right)$ respectively, due to most of the studied conditions, job perception \& supportive services among nurses in $\mathrm{MCH}$ centers are younger in age.

Table 6. Correlation between the quality of life factors scores and nurses' personal characteristics at primary health centers in Assiut city $(\mathrm{n}=85)$

\begin{tabular}{llllll}
\hline \multirow{2}{*}{$\begin{array}{l}\text { Personal } \\
\text { Characteristics }\end{array}$} & Quality of work life Factors & & \\
\cline { 2 - 6 } & Work environment & $\begin{array}{l}\text { Relations with a } \\
\text { manager }\end{array}$ & Work conditions & Job perception & $\begin{array}{l}\text { Supportive } \\
\text { services }\end{array}$ \\
\hline Age\# & $6.614^{* *}$ & $11.318^{* *}$ & $8.540^{* *}$ & $6.893^{* *}$ & $8.419^{* *}$ \\
Qualification & 2.823 & 1.979 & 0.601 & 1.686 & 1.198 \\
Marital status & 0.364 & $3.404^{*}$ & 0.486 & $2.784^{*}$ & 1.841 \\
Years of experience & 2.542 & 0.631 & 0.531 & 0.428 & 0.916 \\
\hline
\end{tabular}

${ }^{\#}$ Pearson correlation coefficient; ${ }^{*} p$-value $\leq .05 ;{ }^{* *} p$-value $\leq .001$.

\section{Discussion}

Quality of work life is some regarding the almost important factors up to expectation shape the organizational behaviors of employees. These factors include work/job environment, relations with directors, work conditions, work perception, support services and wage. ${ }^{[18]}$

The current study was designed to explore the relationship between nurses' empowerment and quality of work life. Personal characteristics data of the studied nurses promoted as the nursing career remains a feminized profession, as ought to have an effect on work-life quality within number roles they put into effect (wife, mother, housewife, and employee) the place she/he cares concerning patients, family, and pals or ignoble community members before her own needs. The findings of the current study illustrated that the studied nurses were agreed with their work life in the aspect of work conditions, job perception, \& work environment. While they disagreed with the aspect of relations with a manager \& supportive services are found in the primary health care setting (see Table 3). These findings were unsupported with the findings of Almalki et al. ${ }^{[19]}$ who studied the quality of work life among primary health care nurses in the Jazan region, Saudi Arabia. Where he determined so the dominance on nurses had been comfortable together with theirs co-workers, satisfied in conformity with lie nurses yet had a experience concerning belonging in their workplaces, while he were disenchanted with theirs employment life. The fundamental influencing elements were unsuited assignment hours, scarcity over services because nurses, inability in conformity with balance work together with family needs, decrease of vacations day because nurses then their families, poor staffing, management then control practices, deficiency concerning professional improvement opportunities, yet an incompatible cause surroundings into terms of the degree concerning security, patient outweigh components or equipment, and the community's view of nursing and an inadequate salary.

The current study findings revealed that the highest mean and standard deviation for nurses' quality of work life factors were in work conditions and work environment (see Table 3). This might be due to effective leadership style that follow the administrative policies which create a positive work condition and environment and help to deal with problems occur with nurses' and change nurses' perceptions to be positive toward their jobs. These results were in agreement with Kotze ${ }^{[20]}$ who stated that work life quality is often considered in two ways, the first is the removal of negative 
aspects of work and working conditions and another way is the modification of work and working conditions to enhance the capability of employees.

The findings of the current study are unsupported by the findings of Daubermann \& Tonete ${ }^{[21]}$ who studied the quality of work life of nurses in primary health care in Brazil and demonstrated that the studied nurses were satisfied regarding quality of work life, and barriers were identified that compromised the quality of life of them determined primarily by the insufficient materials, manpower and environmental resources, as well as the established work process.

Also the current study findings were consistent with Ramesh et al. ${ }^{[22]}$ study, who indicated that their studied nurses have the autonomy to take decisions about patient care, (74.9\%) had been disabled according to stability their employment or family lives (98.2\%) were stressed in their work and (81.3\%) of nurses were incapable in imitation of fulfilled theirs job into the era available.

Moreover, the results of González-Cruz et al.'s ${ }^{[23]}$ study confirmed that amount of dissatisfaction can located into the nursing professional's QWL among public health clinics within all dimensions. This finding is inconsistent with our findings.

Based on our findings a meaningful negative relationship between nurses' empowerment and quality of work life was confirmed (see Table 4). The studied nurses expressed that the recognized poor communication and relations among the health team and shortage in supplies and equipment, and they feel unfair distribution of salary among $\mathrm{MCH}$ centers.

Supporting to the study finding Meng ${ }^{[24]}$ illustrated that nurse empowerment at their working environment will give rise to growth of performance so will threaten the organizational productivity because less empowered nurses will have less work satisfaction and quality of nursing work life.

Inconsistent with the study findings, Mokhtarian et al. ${ }^{[25]}$ clarified that the meaningful relation between empowerment and quality of work life which shows representatives' potential abilities and capacities will thrive and they can accomplish more elevated amounts of execution in their work if sufficient condition in the working environment is upheld. As such, through nature of work-life enhancement fundamental grounds and essentials for empowerment will be given, and through raising the sentiment of occupation importance, feeling of effect, trust, independence, and feeling of power, the critical achievement will be picked up.

Another study done by Donahue ${ }^{[26]}$ which is incongruent with our study findings and found a significant relation be- tween the perception of nurse empowerment in obtaining information, opportunities, support and resources have a positive relation with work life quality. In addition Winasih ${ }^{\text {[27] }}$ found that job satisfaction is influenced by work environment factor which influence to quality of work life of nurse professionally in supportive working environment to create high achieving nurse, high value, beneficial to self and positively impact to quality of hospital .

Furthermore, the current study showed significant positive correlations between age and work life quality factors (see Table 6). This might be due to the majority of studied nurses are young and had interest and talent to work and the $\mathrm{MCH}$ center activities are not a workload place. This finding was supported by Dehghan et al. ${ }^{[28]}$ who found a close correlation between age and quality of work life. The same results also found in the study of Dargahi et al. ${ }^{[29]}$ and Boonrod ${ }^{[30]}$ assess the quality of working life perceptions of professional nurses at Phramongkutklao Hospital. On the other hand, our results were contradicted with the study of Prasad ${ }^{[31]}$ who evaluate the quality of work life: A study of the public sector nurses in West Bengal and found that there is significant difference between demographics variables and quality of work life accepted except for age range. The contradiction with this study may be due to chosen of different age group.

\section{Conclusion}

Empowerment had a direct influence on QWL. Empowerment needs to be created within primary health care centers for nursing services so that nurses as front liners should have sufficient strength to have a major impact on client health services, because the study illustrated a significant negative correlation between quality of work life and empowerment factors and positive correlations with personal characteristics (age, qualification, marital status, and years of experience) among studied nurses at Primary Health care Centers in Assiut City.

\section{Recommendations}

(1) Workshops on the quality of work life skills for nurses and nurse managers should be done periodically.

(2) Nurse Managers in $\mathrm{MCH}$ centers should provide nurses by sufficient information, guide and resources.

(3) Nurses in primary health centers have to remain allowed to participate in decision making process to empower them, as like properly as growing theirs effect on autonomy.

(4) First line nurse managers should periodically have nursing group meeting to verbalized, vitalize and support peer and social interaction.

(5) Further Nursing studies are required to be done on 
the empowerment, organizational commitment, and nurses' retention at $\mathrm{MCH}$ centers as the service introduced in $\mathrm{MCH}$ are specified.

\section{ACKNOWLEDGements}

I would like to thank nurses working at primary health care centers in Assiut City who accept to share in the research.

\section{CONFLICTS OF INTEREST Disclosure}

The authors declared that they have no competing interests.

\section{REFERENCES}

[1] Ma R, Alampay R, France E. Psychological empowerment, job satisfaction, and performance among Filipino service workers. Asian Journal of Social Psychology. 2006; 9(4): 72-90. https ://doi . or $\mathrm{g} / 10.1111 / \mathrm{j} .1467-839 \mathrm{X} .2006 .00177 . \mathrm{x}$

[2] Yi Liu B. Taiwanese Nurses' Empowerment and Participation in Decision Making, Doctoral Degree, Faculty of the Graduate School, the University of Texas at Austin. 2008; 30(49): 413.

[3] Connell J. Call centers, quality of work life and HRM practices: An in-house/outsourced comparison. Employee Relations. 2009; 31: 363-381. https://doi.org/10.1108/01425450910965423

[4] Adhikari D, Gautam D. Labour legislation for improving quality of work life in Nepal. International Journal of Law Management. 2010; 52: 40-53. https://doi.org/10.1108/17542431011018534

[5] Mosadeghrad A, Ferlie E, Rosenberg D. A study of the relationship between job stress, quality of working life and turnover intention among hospital employees. Health Serv. Manage. Res. 2011; 24: 170-181. PMid:22040944 https://doi.org/10.1258/hsmr .2011 .011009

[6] Mahdad A, Mahdavi Rad N, Golparvar M. The relationship between quality of work life (QWL) and its components whit organizational commitment and its components. New Findings in Psychology. 2011; 5(20): 53-41.

[7] Zmani S. Study of the Relationship between Empowerment and Quality of Staff Working Life of Iran Telecommunication Company. International Journal of Humanities and Cultural Studies. 2016; 2(4): 1144-1154.

[8] Dewettinck K, van Ameijde M. Linking leadership empowerment behaviour to employee attitudes and behavioral intentions: Testing the mediating role of psychological empowerment. Emerald Group Publishing Limited. 2011; 40(3): 284-305. https://doi .org/10 $.1108 / 00483481111118621$

[9] Rantanen J, Kinnunen U, Mauno S, et al Introducing Theoretical Approaches to Work-Life Balance and Testing A New Typology among Professionals, In Creating Balance? Springer Berlin Heidelberg. 2011; 27-46. https://doi.org/10.1007/978-3-642 $-16199-5$

[10] World Health Organization. The World Health Report 2008: primary health care now more than ever. Geneva, Switzerland. 2008.

[11] Pan American Health Organization and World Health Organization. Public health nursing and essential functions of public health: basis for professional practice in the XXI century. 2001. Available from: http://www.ops.org.bo/textocompleto/ise20 596.pdf.Spanish

[12] Renuka Devi B, Hajamohideen OM. A Study on Quality of Work Life among Nurses Working In Private Hospitals an Thanjavur, Tamilnadu. IOSR Journal of Business and Management. 2018; 20(4): 61-63.

[13] Washeya F. Factors influencing retention of professional nurses in a public health care facility in windhoek, Namibia. Thesis presented in partial fulfillment of the requirements for the degree of Master of Nursing Science in the Faculty of Medicine and Health Sciences Stellenbosch University. 2018.

[14] Nantsupawat A, Srisuphan W, Kunaviktikul W, et al. Impact of nurse work environment and staffing on hospital nurse and quality of care in Thailand. J Nurs Scholarsh. 2011; 43(4). PMid:22018093 https://doi.org/10.1111/j.1547-5069.2011.01419.x

[15] Lacey S, Teasley S, Cox K, et al. Development and testing of an organizational job satisfaction tool: increasing precision for strategic improvements. Journal of Nursing Administration. 2011; 41(1): 1522. PMid:21157239 https : //doi .org/10.1097/NNA . 0b013e31 82002871

[16] Shelton S. Employees, Supervisors, and Empowerment in the public sector: The Role of Employee Trust, Unpublished Doctoral degree thesis, Graduate Faculty of North Carolina State University. 2002; 30-35.

[17] Brooks B. Development of an instrument to measure the quality of nursing work life. Doctoral dissertation, the University of Illinois at Chicago. 2001

[18] Zhao X, Tao S, QiuRu C, et al. The impact of quality of work life on job embeddedness and affective commitment and their co-effect on turnover intention of nurses. Journal of Clinical Nursing. 2013.

[19] Almalki M, FitzGerald G, Clark M. Quality of work life among primary health care nurses in the Jazan region, Saudi Arabia: a cross-sectional study. Human Resources for Health. 2012; 10: 30. PMid:22971150 https://doi.org/10.1186/1478-4491-10-3 0

[20] Kotze M. The nature and development of the construct quality of work life. Acta Academia. 2005; 37(2): 96-122.

[21] Daubermann D, Tonete V. Quality of work life of nurses in primary health care. Acta paul. enferm. 2012.

[22] Ramesh N, Nisha C, Josephine A, et al. A study on quality of work life among nurses in a medical college hospital in Bangalore. Nacional Journal of Community Medicine. 2013; 4(3): 471-474.

[23] González-Cruz N, Peñarrieta-de Córdova1 M, Castañeda-Hidalgo H, et al. Quality of work life in primary care of nursing professionals in public health clinics in Tampico, Mexico. Journal of Hospital Administration. 2016. https://doi .org/10.5430/jha.v5n3p90

[24] Meng L. Relationships among structural empowerment, psychological empowerment, intent to stay and burnout in nursing field in mainland China. International Journal of Nursing Practice. 2015.

[25] Mokhtarian F, Mohammadi R, Hossieni S. Impact on Improving the Quality of Working Life of Employees, Their Psychological Empowerment. The First National Conference on Human Resources Training Patterns Universities, Islamic Azad University, South Tehran. 2012.

[26] Donahue M, et al. The relationship between nurses perceptions of empowerment and patient satisfaction. 2008; 21: 2-7. PMid: 18226757 https://doi.org/10.1016/j.apnr.2007.11.001

[27] Winasih R. Analysis of the influence of organizational culture and QNWL on the performance and job satisfaction of nurses in Dr Soetomo General Hospital Surabaya. Journal of Nursing. 2015; 
10(2): 332-342. https://doi.org/10.20473/jn.V10I22015. 332-342

[28] Dehghan N, Salehi T, Noghabi A. Quality of work life and productivity among Iranian Nurses. Journal for the Australian Nursing Profession. 2012; 39(1): 106-18. PMid:21955271 https://doi.or $\mathrm{g} / 10.5172 /$ conu. 2011.39.1.106

[29] Dargahi H, Changizi V, Jazayeri Gharabagh E. Radiology employees' quality of work life. Acta Med Iran. 2012; 50(4): 250-6.
[30] Boonrod W. Quality of working life: perceptions of professional nurses at Phramongkutklao Hospital. J. Med. Assoc. Thai. 2009; 92(Suppl. 1): S7-15.

[31] Prasad M. An evaluation of the quality of work life: A study of the public sector nurses in West Bengal. Asian J. Nur. Edu. and Research. 2016; 6(2): 199-203. https://doi.org/10.5958/2349-2996. 2016.00036 .7 